\section{PONAŠAJNE I \\ SOCIO-EMOCIONALNE KOMPETENCIJE SREDNJOŠKOLACA: VALIDACIJA HRVATSKE INAČICE BERS-2 UPITNIKA}

Izvorni znanstveni članak

Primljeno: prosinac, 2020.

Prihvaćeno: veljača, 2021.

UDK 159.9.072-053.6

DOI 10.3935/ljsr.v28i1.378

Ina Reić Ercegovac ${ }^{1}$ orcid.org/0000-0003-4228-6054

Katedra za psihologiju

Filozofski fakultet

Sveučilište u Splitu

Toni Maglica²

orcid.org/0000-0002-0716-0037

Odsjek za rani i predškolski

odgoj

Filozofski fakultet

Sveučilište u Splitu

Maja Ljubetić ${ }^{3}$

orcid.org/0000-0002-9344-5580

Odsjek za pedagogiju

Filozofski fakultet

Sveučilište u Splitu

Ključne riječi:

adolescenti,

BERS-2 upitnik, socio-emocionalne kompetencije

1 izv. prof. dr. sc. Ina Reić Ercegovac, psihologinja, e-mail: inareic@ffst.hr

2 dr. sc. Toni Maglica, socijalni pedagog, poslijedoktorand, e-mail: tmaglica@ffst.hr

3 prof. dr. sc. Maja Ljubetić, pedagoginja, e-mail: ljubetic@ffst.hr 
konvergentnu valjanost hrvatskog prijevoda BERS-2 upitnika. Djevojke su, u odnosu na mladiće, ostvarile značajno više rezultate na mjerama školskog funkcioniranja $i$ interpersonalnih snaga, dok su intrapersonalne snage te uključenost u obitelj djevojke i mladići procijenili sličnima. Rezultati su raspravljeni u kontekstu podataka o izvornoj inačici BERS-2 upitnika, podataka o provjerama njegovih obilježja u drugim istraživanjima te s obzirom na postojeće spoznaje o ponašajnim i socio-emocionalnim kompetencijama adolescenata. Ograničenja provedenog istraživanja, kao i potreba daljnje provjere konstruktne valjanosti upitnika BERS-2, iznesena su u zaključnom dijelu.

\section{UVOD}

Socio-emocionalne kompetencije djece razvijaju se od najranijeg djetinjstva u različitim razvojnim kontekstima među kojima najvažniju ulogu imaju mikrosustavi obitelj, vrtić/škola i vršnjaci kao primarna okruženja u kojima dijete živi, raste, razvija se i uči (Maggi i sur., 2010.; Bernier i sur., 2012.; Böddi i Serfőző, 2019.). Istraživanja diljem svijeta već dulje vrijeme konzistentno ukazuju kako ulaganje u socio-emocionalne kompetencije dovodi do unaprjeđenja pozitivnih i reduciranja nepoželjnih ponašanja te doprinosi akademskom postignuću i dobrobiti djece i mladih (Payton i sur., 2008.; Durlak i sur., 2015.; Cefai i sur., 2018.; Mahoney, Durlak i Weissberg, 2019.). Unatoč pozitivnim pomacima u odgojno-obrazovnom sustavu u implementaciji procesa socio-emocionalnog učenja, ova skupina kompetencija još uvijek nije optimalno zastupljena u školskom sustavu (Munjas Samarin i Takšić, 2009.). Socio-emocionalno učenje je posebno važno uzme li se u obzir uloga tih kompetencija u cjelovitom razvoju djece i mladih (Payton i sur., 2008.; Durlak i sur., 2011.; Schonert-Reichl, Kitil i Hanson-Peterson, 2017.). Socio-emocionalno učenje prepoznato je kao bitan aspekt obrazovanja djece i nužno obilježje svih uspješnih napora u reformi škole (Zins i sur., 2004.). Ove kompetencije shvaćaju se kao dio šireg koncepta otpornosti jer nedvojbeno imaju važnu ulogu u suočavanju s brojnim izazovima odrastanja. Istodobno, one pripadaju i skupini zaštitnih čimbenika za razvoj niza poteškoća, kako u emocionalnom, tako i u ponašajnom području (Denham i Brown, 2010.; CASEL, 2017.).

Pri pokušaju definiranja i imenovanja ključnih socio-emocionalnih kompetencija, različiti autori i modeli nude različite konceptualizacije, ali većina uključuje skupinu intrapersonalnih (primjerice, regulacija emocija, svijest o sebi) i interpersonalnih kompetencija (primjerice, briga za druge, sposobnost ostvarivanja kvalitetne komunikacije). Prema modelu Bar-On (2005.), socio-emocionalne kompetencije uključuju niz vještina važnih za uspješnost u razumijevanju i izražavanju sebe samih, drugih, povezivanju s drugima i suočavanju sa svakodnevnim zahtjevima. CASEL model (CASEL, 2007., 2015.) uključuje pet skupina međusobno povezanih kompetencija: samosvijest, upravljanje sobom, socijalna svijest, socijalne vještine te odgovorno 
donošenje odluka uvažavajući norme i društvene standarde. Ovaj model iznimno je raširen u većem dijelu država Europe, Australije i Sjedinjenih Američkih Država (Cefai i sur., 2018.). Nešto širu konceptualizaciju socio-emocionalnih kompetencija koja uključuje i određene kognitivne aspekte nude Cohen (2001.) te Cohen i Sandy (2003.) navodeći čak osam ključnih skupina socio-emocionalnih kompetencija koje uspješno predviđaju optimalne razvojne ishode kod djece - svijest o sebi i drugima, refleksiju i empatiju, kreativnost i fleksibilnost u rješavanju problema i odlučivanju, reguliranje impulsa, kapacitet za suradnju, vještine jasnog i neposrednog komuniciranja, samo-motivaciju te sposobnost stvaranja i zadržavanja prijateljskih odnosa.

Bez obzira na složenost koncepta i različitosti u određivanju ključnih elemenata, kao jedan od izazova ističe se i mjerenje socio-emocionalnih kompetencija na način koji će osigurati odgovarajuću procjenu aktualne razine razvijenosti tih kompetencija, kao i praćenje kroz različite intervencijske tretmane (Gil-Olarte, Palomera i Brackett, 2006.; Humphrey i sur., 2011.). Naime, uz terminološke razlike, preklapanje konstrukata i različitosti u objašnjavanju elemenata koji čine određene socio-emocionalne kompetencije, ključni izazov predstavljaju i različite metode procjene među zemljama, regijama i kulturama (Salzburg Global Seminar, 2016., prema Cefai i sur., 2018.). $\mathrm{U}$ istraživačkom smislu, osim navedenog, javlja se i pitanje valjanosti i pouzdanosti brojnih mjera koje se koriste $u$ istraživanjima socio-emocionalnih kompetencija. Nedvojbeno je važno imati valjane i pouzdane instrumente koji bi, s jedne strane, bili jednostavni i ne prezahtjevni za primjenu na uzorcima djece i adolescenata, a s druge strane, uključili sve ključne kompetencije i time praktičarima omogućili dovoljno valjanih i pouzdanih informacija na kojima bi mogli temeljiti svoje procjene i planirati preventivne i/ili intervencijske aktivnosti. To je od osobite važnosti jer kvalitetno procjenjivanje predstavlja osnovni alat za stalno poboljšavanje i izgradnju kapaciteta u području socio-emocionalnog učenja te kao takvo predstavlja jedan od ključnih elemenata, kako dosadašnjih, tako i budućih istraživanja (Blythe, Weissberg i Durlak, 2019.; The Aspen Institute National Commission on Social, Emotional and Academic Development, 2019.).

\section{BERS-2 upitnik ponašajnih i socio-emocionalnih kompetencija}

U okviru pristupa socio-emocionalnom učenju kao promicanju i jačanju snaga kod djece i mladih razvijen je upitnik BERS-2 (Epstein, 2004.) s ciljem otkrivanja pozitivnih aspekata ponašajnih i socio-emocionalnih kompetencija djece i mladih u odgojno-obrazovnom, zdravstvenom i sustavu socijalne skrbi. Namijenjen je djeci i mladima u dobi od 5 do 18 godina. Upitnik nudi mogućnost otkrivanja razvijenosti 
specifičnih snaga djece i mladih te računanja ukupnog indeksa koji bi upućivao na ukupne resurse djeteta za suočavanje s izazovima svakodnevnog funkcioniranja ili pak aktivnog rada na rješavanju određenih poteškoća u nekom području života. Upitnikom je moguće izmjeriti interpersonalne, intrapersonalne i afektivne snage djeteta, uključenost u obitelj i školsko funkcioniranje. Interpersonalne snage odnose se na djetetove sposobnosti kontroliranja emocija i ponašanja u socijalnim situacijama (Epstein, 2004.). Intrapersonalne snage odnose se na djetetovo poimanje vlastitih kompetencija i postignuća, a afektivne na pružanje i prihvaćanje emocija od drugih (Epstein, 2004.). Uključenost u obitelj mjeri odnose u obitelji i djetetovo sudjelovanje u obiteljskom životu, a školsko funkcioniranje kompetencije u školskim aktivnostima i zadacima (Epstein, 2004.). lako se široko upotrebljava u školskom kontekstu ili ustanovama socijalne skrbi koje skrbe o djeci s poremećajima u ponašanju, u literaturi ne postoji mnogo podataka o njegovim psihometrijskim značajkama, posebno konstruktnoj valjanosti. Pretraživanjem literature, moguće je naići na navode autora skale o njegovoj dobroj pouzdanosti tipa unutarnje konzistencije, odličnoj test-retest pouzdanosti te dobroj konstruktnoj valjanosti, pri čemu se navode vrijednosti CFI = 0,995; TLI = 0,986 te NFI = 0,995 (Epstein, 2004.) koje upućuju na izuzetno dobro pristajanje podataka pet-faktorskom modelu. Ipak, vrijednost RMSEA bila je značajno viša od preporučene i iznosila je 0,12 na uzorku djece te 0,15 na uzorku roditelja (Furlong i sur., 2007.).

Diskriminativna valjanost ispitana primjenom upitnika na skupini djece s i bez emocionalnih poteškoća pokazala je zadovoljavajuću valjanost (Reid i sur., 2000.; Epstein, 2004.). Validacija upitnika na uzorku finskih osnovnoškolaca pokazala je zadovoljavajuću strukturu upitnika, s nekoliko odstupanja od izvornika. U inačici za adolescente, dvije su čestice izostavljene zbog niskih zasićenja, slično kao i u inačici za roditelje, dok je u inačici za nastavnike izostavljena jedna čestica. Tako prepravljeni modeli pokazali su zadovoljavajuće parametre pristajanja, izuzev nešto viših vrijednosti RMSEA u skupini roditelja i nastavnika (Sointu i sur., 2014.). Neka su istraživanja utvrdila visoke koeficijente pouzdanosti na različitim uzorcima djece i mladih s obzirom na spol i etničku pripadnost, kao i zadovoljavajuću konvergentnu valjanost u odnosu na rezultate na CBCL (Child Behavior Checklist) i SFSS (Symptoms and Functioning Severity Scale) (Duppong Hurley i sur., 2015.). Prediktivnu valjanost upitnika potvrdili su Uhing, Mooney i Ryser (2005.) u istraživanju adolescenata s i bez emocionalnih poteškoća pri čemu je ukupni indeks snaga bio značajno niži u skupini s emocionalnim poteškoćama.

Furlong i suradnici (2007.) su u validaciji upitnika i ispitivanju konstruktne valjanosti pokazali da četverofaktorska struktura bolje odgovara podacima nego peterofaktorski model pri čemu je od početnih 52 ostalo 37 čestica, raspoređenih nešto drugačije nego u izvorniku. Naime, na jednom su se faktoru izdvojile čestice koje u izvorniku 
pripadaju interpersonalnim, intrapersonalnim i afektivnim snagama; na drugom faktoru izdvojilo se sedam čestica koje se odnose na školsko funkcioniranje u odnosu na devet čestica izvornika; treći faktor sačinjavalo je šest čestica iz izvorne interpersonalne skale, a četvrti faktor devet čestica koje su bile kombinacija dviju podskala izvornika - obiteljske uključenosti i intrapersonalnih snaga. Konstruktna valjanost španjolske inačice upitnika na uzorku roditelja predadolescenata i ranih adolescenata pokazala je bolje pristajanje trofaktorskom modelu, pri čemu su autori utvrdili faktore samokontrole, školskog funkcioniranja i emocionalnog zdravlja (Sharkey i sur., 2009.).

Konstruktna valjanost hrvatske inačice ovog upitnika provjeravana je u istraživanju Merkaš (2012.), gdje je utvrđeno dobro pristajanje podataka jednofaktorskom modelu (nadređeni faktor - ukupni indeks snaga te pet faktora drugog reda), uz zadovoljavajuće pouzdanosti svih podskala koje su se na poduzorku adolescenata kretale od 0,73 do 0,88. S obzirom da su neka istraživanja uputila na zadovoljavajuću konstruktnu valjanost upitnika (Epstein, 2004.; Merkaš, 2012.), a neka ne (Furlong i sur., 2007.) te da na našim uzorcima nema dostatnih podataka o konstruktnoj valjanosti, primarni cilj ovoga istraživanja bio je provjeriti strukturu hrvatskog prijevoda BERS-2 upitnika te njegovu konvergentnu valjanost na uzorku adolescenata, a potom provjeriti spolne i dobne specifičnosti kompetencija. Pritom su postavljeni sljedeći istraživački problemi:

1. Ispitati strukturu hrvatskog prijevoda BERS-2 upitnika primjenom eksploratorne faktorske analize.

2. Provjeriti pristajanje podataka pretpostavljenom modelu (temeljem rezultata EFA) primjenom konfirmatorne faktorske analize.

3. Utvrditi pouzdanost rezultata na podskalama upitnika BERS-2.

4. Ispitati povezanost između rezultata na podskalama BERS-2 upitnika i emocionalne kompetentnosti, zadovoljstva obitelji te školskog uspjeha.

5. Ispitati razlikuju li se rezultati na podskalama BERS-2 upitnika s obzirom na dob i spol adolescenata.

\section{METODOLOGIJA ISTRAŽIVANJA}

\section{Uzorak}

U prigodnom uzorku sudjelovalo je 849 adolescenata (56,3\% adolescentica), učenika srednjih škola iz urbane sredine. S obzirom na vrstu škole, u uzorku je bilo $7 \%$ učenika dvogodišnjih i trogodišnjih strukovnih škola, 56\% učenika srednjih četverogodišnjih i petogodišnjih strukovnih škola te $37 \%$ učenika gimnazija. Struktura uzorka s obzirom na dob i spol prikazana je u Tablici 1. Većina sudionika dolazi iz dvoroditeljskih obitelji $(83,5 \%)$. 
Tablica 1. Struktura uzorka s obzirom na dob i spol

\begin{tabular}{lccccc}
\hline & $\mathbf{1 5}$ godina & $\mathbf{1 6}$ godina & $\mathbf{1 7}$ godina & $\begin{array}{c}\mathbf{1 8} \text { i } \mathbf{1 9} \\
\text { godina }\end{array}$ & ukupno \\
\hline Učenici & 93 & 110 & 75 & 93 & 371 \\
Učenice & 100 & 113 & 122 & 143 & 478 \\
Ukupno & 193 & 213 & 203 & 236 & $\mathbf{8 4 9}$ \\
\hline
\end{tabular}

\section{Instrumenti}

Upitnik općih podataka sastojao se od nekoliko sociodemografskih pitanja zatvorenog tipa kojima su prikupljeni podaci o spolu, dobi, vrsti škole, općem školskom uspjehu na kraju protekle školske godine te strukturi obitelji.

Upitnik ponašajnih i socio-emocionalnih kompetencija (BERS - Behavioral and Emotional Rating Scale, Epstein, 2004.) sastoji se od 52 čestice, a konstruiran je za potrebe otkrivanja socio-emocionalnih snaga djece i mladih u odgojno-obrazovnom kontekstu s ciljem planiranja i realiziranja različitih preventivnih i intervencijskih aktivnosti u radu s djecom i mladima. Upitnikom je moguće ispitati razvijenost kompetencija u pet područja - intrapersonalnom (11 čestica, primjerice, «Vjerujem u sebe» ili «Znam što dobro radim»), interpersonalnom (15 čestica, primjerice, «Dobar sam prema drugima»), afektivnom (7 čestica, primjerice, «Kad mi je netko drag, dam mu to do znanja»), školskom (9 čestica, primjerice, "Pažljivo pratim nastavu», «Obavljam svoje školske obaveze na vrijeme») i (10 čestica, primjerice, «Osjećam se željeno u svojoj obitelji», "Dobro se slažem sa svojom braćom i sestrama»). Autori upitnika izvijestili su o visokoj pouzdanosti, unutarnjoj valjanosti te konvergentnoj valjanosti na uzorcima djece od predškolske do adolescentne dobi (Epstein, 2004.). Kasnije provjere strukture upitnika nisu dale jednoznačnu potvrdu izvornoj strukturi (Furlong i sur., 2007.). Upitnik je preveden s engleskog na hrvatski jezik pri čemu je korišten standardni postupak povratnog prijevoda (eng. back translation) s ciljem osiguravanja njegove usporedivosti s izvornikom na engleskom jeziku (Hui i Triandis, 1985.; van de Vijver i Hambleton, 1996.). Navedeno je provedeno na način da je prvo napravljen prijevod s engleskog na hrvatski te je potom nezavisni prevoditelj preveo s hrvatskog na engleski.

Upitnik emocionalne kompetentnosti - UEK-15 (Takšić, 2002.) skraćena je inačica izvornog upitnika UEK-45 koji ispituje tri područja emocionalne kompetentnosti - sposobnost uočavanja i razumijevanja emocija (primjerice, «Lako primijetim promjenu raspoloženja svoga prijatelja»), sposobnost izražavanja i imenovanja emocija (primjerice, "Mogu opisati kako se osjećam») te sposobnost upravljanja 
emocijama (primjerice, «Dobro raspoloženje mogu zadržati i ako mi se nešto loše dogodi»). Zadatak sudionika bio je za svaku česticu procijeniti koliko se odnosi na njih zaokruživanjem jednog od pet brojeva (1 - uopće ne, 5 - u potpunosti). U ovom je istraživanju primijenjena skraćena inačica od 15 čestica, za koju autori preporučuju korištenje jednog ukupnog rezultata kao opće procjene individualnih razlika u emocionalnoj kompetentnosti. Stoga su provedene dvije konfirmatorne analize kako bi se odredilo kojem modelu bolje pristaju podaci ovoga istraživanja. Rezultati konfirmatornih analiza pokazali su dobro pristajanje podataka trofaktorskom modelu (GFI $=0,93 ; \mathrm{CFI}=0,90 ; \mathrm{NNFI}=0,89)$, za razliku od jednofaktorskog modela $(\mathrm{GFI}=0,79$; $\mathrm{CFI}=0,71 ; \mathrm{NNFI}=0,66)$ te je stoga zadržana trofaktorska struktura, slično izvornoj inačici upitnika s 45 čestica. Formirana su tri ukupna rezultata za tri podskale upitnika zadovoljavajuće pouzdanosti (Cronbach $\alpha=0,80$ za podskalu izražavanja i imenovanja emocija; Cronbach $\alpha=0,81$ za podskalu uočavanja i razumijevanja emocija), koja je bila nešto niža za podskalu upravljanja emocijama (Cronbach $\alpha=0,66$ ). Parametri asimetričnosti i spljoštenosti raspodjele rezultata na podskalama su se kretali od -0,11 do 1.69 , što udovoljava uvjetima za primjenu parametrijskih postupaka (Trochim i Donnelly, 2006.; Gravetter i Wallnau, 2014.) u daljnjim analizama.

Skala zadovoljstva obitelji sastavni je dio upitnika FACES IV (Olson, Gorall i Tiesel, 2006.). Sastoji se od deset čestica kojima se ispituje zadovoljstvo obiteljskim odnosima (primjerice, bliskost između članova obitelji, količina vremena koju članovi obitelji provode zajedno), a zadatak je sudionika bio procijeniti na skali od 1 do 5 stupanj zadovoljstva (1 - jako nezadovoljan, 5 - jako zadovoljan). Konfirmatorna faktorska analiza potvrdila je dobro pristajanje jednofaktorskog modela podacima $(\mathrm{GFI}=0,91$; $\mathrm{CFI}=0,94$; NNFI = 0,92), pa je formiran jedan ukupan rezultat sumiranjem procjena na svih deset čestica. Pouzdanost skale iznosila je Cronbach $\alpha=0,92$, prosječni rezultat $M=39,32(S D=9,06)$ uz raspon od 10 do 81. S obzirom na parametre asimetričnosti $(-0,83)$ i spljoštenosti $(0,86)$, moguće je zaključiti kako rezultati ne odstupaju značajno od normalne raspodjele (Trochim i Donnelly, 2006.; Gravetter i Wallnau, 2014.), odnosno udovoljavaju uvjetima za primjenu parametrijskih postupaka.

\section{Postupak}

Istraživanje je provedeno tijekom školske godine 2018./2019. te je bilo u potpunosti anonimno i dobrovoljno. Nakon dobivenih dozvola nadležnih tijela pristupilo se prikupljanju podataka u školama koje pohađaju sudionici. Popunjavanje upitnika provodilo se tijekom jednog školskog sata po principu papir-olovka. Na samom početku učenicima je objašnjena svrha i cilj istraživanja, dane su upute o načinu popunjavanja te ih se podsjetilo na anonimnost i dobrovoljnost. Učenici koji su željeli 
sudjelovati potpisali su informirani pristanak. Kako su ispitanici stariji od 14 godina, aktivni pristanak roditelja nije bio potreban (Ajduković i Kolesarić, 2003.), ali učenicima koji su sudjelovali u istraživanju dana je detaljna pisana obavijest za roditelje. Učenici su u svakom trenutku mogli odustati od popunjavanja. U učionici su uvijek bila dva istraživača na raspolaganju za sva pitanja.

\section{Analiza podataka}

U prvom dijelu analize, primijenjeni su postupci eksploratorne i konfirmatorne faktorske analize. S obzirom da je provjeru faktorske strukture upitnika eksploratornom pa potom konfirmatornom faktorskom analizom potrebno provesti na različitim podacima (Cabrera-Nguyen, 2010.), s ciljem provjere faktorske strukture upitnika BERS-2, podaci su nasumično podijeljeni u dvije skupine (tzv. random sampling). Prvi korak bila je primjena EFA na prvoj skupini podataka $\left(N_{1}=423\right)$ uz $M L$ metodu ekstrakcije faktora s obzirom na moguću povezanost među faktorima. Odabrana metoda ekstrakcije faktora bila je primjerena s obzirom da je od ukupno 52 čestice samo jedna imala asimetričnost veću od 2 , a spljoštenost veću od 7 , što su granične vrijednosti koje se preporučuju za primjenu ML metode (Curran, West i Finch, 1996.). $U$ drugom dijelu provedene su konfirmatorne faktorske analize na drugoj polovici podataka $\left(\mathrm{N}_{2}=423\right)$. Pri tome su se kao kriteriji za prihvaćanje modela uzimali neznačajan hi-kvadrat test (odnosno relativan hi-kvadrat manji od 3), NFI, CFI i GFI jednak ili veći od 0,90 (Schermelleh-Engel, Moosbrugger i Müller, 2003.), a RMSEA jednak ili manji od 0,06 (Hu i Bentler, 1999.). U posljednjem dijelu obrade podataka provedene su korelacijske analize s ciljem ispitivanja konvergentne valjanosti upitnika te dvosmjerne analize varijance s ciljem testiranja rodnih i dobnih razlika. Obrada podataka izrađena je primjenom računalne aplikacije STATISTICA13.

\section{REZULTATI}

\section{Eksploratorna faktorska analiza Upitnika BERS-2 na polovici podataka ( $N=423$ )}

Analiza je rezultirala šesterofaktorskom strukturom koja se značajno razlikovala od strukture izvornika (Tablica 2.). Naime, nekoliko čestica imalo je zasićenja manja od 0,30 na svih šest faktora, a neke su čestice imale zasićenja viša od 0,30 na dva ili tri faktora. Također, raspored čestica po faktorima razlikovao se od onog u izvornom upitniku (Epstein i sur., 2004.). Kako bi se pročistila faktorska struktura, u prvom su 
koraku izostavljene čestice koje nisu imale značajna zasićenja ni na jednom faktoru, a potom i one koje su imale zasićenja viša od 0,30 na više faktora. U konačnici je ostala 31 čestica kojom je postignuta relativno "čista faktorska struktura sa značajnim zasićenjem na jednom faktoru, a niskim zasićenjima na ostalim faktorima. Ponovljena eksploratorna faktorska analiza iznjedrila je četverofaktorsko rješenje. Pri tome su se na prvom faktoru izdvojile čestice koje se odnose na uključenost u obitelj. U izvorniku je ovaj faktor sačinjavalo deset čestica, od kojih su u ovoj strukturi ostale tri koje se odnose na slaganje s članovima obitelji i roditeljima. Na drugom su se faktoru izdvojile čestice koje se odnose na školsko funkcioniranje te je na tom faktoru primijećeno najviše slaganja između izvorne strukture i one dobivene u ovom istraživanju. Od izvornih devet čestica koje su činile ovaj faktor, ostalo ih je osam te je još jedna čestica koja je u izvorniku bila sastavni dio podskale interpersonalnih snaga zbog svog značajnog zasićenja dodana ovom faktoru. Na trećem se faktoru izdvojilo 12 čestica koje čine podskalu intrapersonalnih snaga. Ovaj se faktor sastoji od tri čestice koje su izvorno bile sastavni dio podskale intrapersonalnih snaga, pet čestica koje su u izvorniku bile sastavni dio podskale afektivnih snaga te dvije čestice koje su u izvorniku činile podskalu uključenosti u obitelj. Na posljednjem, četvrtom faktoru izdvojilo se sedam čestica koje se odnose na interpersonalne snage, a u odnosu na izvornik, faktor sadrži šest čestica izvorne podskale interpersonalnih snaga te jednu česticu izvorne podskale intrapersonalnih snaga. Provjerom pouzdanosti pokazalo se da dobiveni faktori imaju zadovoljavajuće koeficijente pouzdanosti pri čemu je za podskalu uključenosti u obitelj Cronbach $\alpha=0,84$, za podskalu školskog funkcioniranja Cronbach $\alpha=0,83$, za podskalu intrapersonalnih snaga Cronbach $\alpha=$ 0,81 te za podskalu interpersonalnih snaga Cronbach $\alpha=0,76$. 
Tablica 2. Početna faktorska struktura hrvatske inačice izvornog BERS-2 upitnika

\begin{tabular}{|c|c|c|c|c|c|c|}
\hline $\begin{array}{c}\text { Čestice prema izvornoj } \\
\text { strukturi }\end{array}$ & $\mathbf{F 1}$ & $\mathbf{F} 2$ & F3 & F4 & F5 & F6 \\
\hline Uključenost u obitelj 1 & 0,65 & 0,09 & 0,06 & 0,16 & 0,09 & 0,17 \\
\hline Uključenost u obitelj 2 & 0,28 & $-0,03$ & 0,10 & 0,32 & 0,09 & 0,01 \\
\hline Afektivne snage 1 & 0,07 & $-0,04$ & 0,13 & 0,39 & 0,05 & 0,10 \\
\hline Uključenost u obitelj 3 & 0,18 & 0,12 & 0,05 & 0,35 & 0,12 & 0,23 \\
\hline Intrapersonalne snage 1 & 0,20 & 0,04 & $-0,06$ & 0,30 & 0,20 & 0,62 \\
\hline Afektivne snage 2 & 0,04 & 0,03 & 0,2 & 0,42 & 0,07 & 0,23 \\
\hline Uključenost u obitelj 4 & 0,81 & 0,12 & 0,08 & 0,24 & 0,08 & 0,14 \\
\hline Intrapersonalne snage 2 & 0,14 & $-0,09$ & 0,09 & 0,20 & 0,11 & 0,23 \\
\hline Afektivne snage 3 & 0,15 & 0,17 & 0,08 & 0,62 & 0,12 & 0,23 \\
\hline Interpersonalne snage 1 & 0,16 & 0,25 & 0,16 & 0,29 & $-0,01$ & 0,41 \\
\hline Uključenost u obitelj 5 & 0,20 & 0,12 & 0,15 & 0,38 & $-0,03$ & 0,05 \\
\hline Interpersonalne snage 2 & $-0,01$ & 0,15 & 0,49 & 0,38 & $-0,23$ & $-0,04$ \\
\hline Afektivne snage 4 & 0,02 & 0,10 & 0,51 & 0,39 & $-0,10$ & $-0,09$ \\
\hline Školsko funkcioniranje 1 & 0,12 & 0,36 & 0,24 & 0,13 & 0,02 & 0,20 \\
\hline Uključenost u obitelj 6 & 0,80 & 0,15 & 0,11 & 0,16 & 0,08 & 0,20 \\
\hline Interpersonalne snage 3 & 0,14 & 0,26 & 0,15 & $-0,00$ & $-0,12$ & 0,42 \\
\hline Interpersonalne snage 4 & 0,03 & 0,35 & 0,27 & 0,06 & $-0,10$ & 0,26 \\
\hline Interpersonalne snage 5 & 0,10 & 0,09 & 0,37 & 0,20 & $-0,08$ & 0,34 \\
\hline Uključenost u obitelj 7 & 0,17 & 0,14 & 0,02 & 0,15 & 0,02 & 0,10 \\
\hline Intrapersonalne snage 3 & 0,13 & 0,03 & 0,39 & 0,04 & 0,12 & 0,05 \\
\hline Intrapersonalne snage 4 & 0,07 & 0,04 & 0,15 & 0,60 & 0,20 & 0,00 \\
\hline Intrapersonalne snage 5 & 0,14 & 0,17 & 0,02 & 0,19 & 0,13 & 0,29 \\
\hline Afektivne snage 5 & 0,08 & 0,14 & 0,06 & 0,67 & 0,19 & 0,09 \\
\hline Školsko funkcioniranje 2 & 0,06 & 0,70 & 0,08 & 0,21 & 0,01 & 0,11 \\
\hline Afektivne snage 6 & 0,20 & 0,01 & 0,15 & 0,58 & 0,39 & 0,21 \\
\hline Intrapersonalne snage 6 & 0,17 & 0,09 & 0,14 & 0,26 & 0,39 & 0,49 \\
\hline Intrapersonalne snage 7 & 0,13 & 0,11 & 0,14 & 0,11 & 0,38 & 0,64 \\
\hline Interpersonalne snage 6 & 0,04 & 0,07 & 0,41 & 0,08 & 0,17 & 0,40 \\
\hline Uključenost u obitelj 8 & 0,27 & 0,23 & 0,18 & 0,11 & 0,22 & 0,08 \\
\hline Interpersonalne snage 7 & 0,07 & 0,13 & 0,54 & 0,06 & 0,16 & 0,08 \\
\hline
\end{tabular}




\begin{tabular}{lcccccc}
\hline \multicolumn{1}{c}{$\begin{array}{c}\text { Čestice prema izvornoj } \\
\text { strukturi }\end{array}$} & F1 & F2 & F3 & F4 & F5 & F6 \\
\hline Školsko funkcioniranje 3 & 0,01 & 0,72 & 0,18 & 0,13 & 0,04 & $-0,03$ \\
Intrapersonalne snage 8 & 0,18 & 0,05 & 0,19 & 0,32 & 0,41 & 0,18 \\
Interpersonalne snage 8 & 0,11 & 0,17 & 0,49 & 0,12 & 0,17 & $-0,00$ \\
Afektivne snage 7 & 0,08 & $-0,01$ & 0,36 & 0,26 & 0,30 & 0,04 \\
Interpersonalne snage 9 & 0,05 & 0,06 & 0,58 & 0,17 & 0,01 & 0,17 \\
Uključenost u obitelj 9 & 0,42 & 0,21 & 0,23 & 0,23 & 0,20 & 0,14 \\
Interpersonalne snage 10 & 0,17 & 0,18 & 0,49 & $-0,04$ & 0,08 & 0,26 \\
Intrapersonalne snage 9 & 0,13 & $-0,00$ & 0,26 & 0,19 & 0,47 & 0,09 \\
Školsko funkcioniranje 4 & 0,04 & 0,71 & 0,13 & 0,02 & 0,13 & 0,12 \\
Školsko funkcioniranje 5 & 0,18 & 0,42 & $-0,05$ & $-0,03$ & 0,05 & 0,09 \\
Školsko funkcioniranje 6 & 0,08 & 0,18 & 0,03 & 0,06 & 0,18 & 0,13 \\
Intrapersonalne snage 10 & 0,15 & 0,14 & 0,15 & 0,23 & 0,49 & 0,23 \\
Interpersonalne snage 11 & 0,02 & 0,20 & 0,49 & 0,08 & 0,28 & 0,04 \\
Interpersonalne snage 12 & 0,03 & 0,04 & 0,43 & 0,34 & 0,18 & 0,04 \\
Uključenost u obitelj 10 & 0,32 & 0,18 & 0,38 & 0,07 & 0,28 & 0,20 \\
Interpersonalne snage 13 & $-0,03$ & 0,20 & 0,65 & 0,13 & 0,02 & 0,06 \\
Školsko funkcioniranje 7 & 0,02 & 0,67 & 0,12 & 0,11 & 0,02 & $-0,01$ \\
Intrapersonalne snage 11 & 0,01 & 0,18 & 0,20 & 0,24 & 0,39 & 0,01 \\
Interpersonalne snage 14 & 0,05 & 0,06 & 0,53 & 0,13 & 0,40 & 0,03 \\
Interpersonalne snage 15 & 0,05 & 0,32 & 0,36 & $-0,01$ & 0,23 & 0,17 \\
Školsko funkcioniranje 8 & 0,09 & 0,46 & 0,19 & $-0,06$ & 0,13 & 0,07 \\
Školsko funkcioniranje 9 & 0,06 & 0,69 & 0,14 & 0,01 & 0,02 & 0,00 \\
\hline \% objašnjene varijance & $5 \%$ & $8 \%$ & $8 \%$ & $7 \%$ & $4 \%$ & $5 \%$ \\
\hline & & & & & & \\
\hline
\end{tabular}


Tablica 3. Završna faktorska struktura hrvatske inačice BERS-2 upitnika

\begin{tabular}{|c|c|c|c|c|c|}
\hline $\begin{array}{c}\text { Čestice prema izvornoj } \\
\text { strukturi }\end{array}$ & $\begin{array}{c}\text { Čestice prema novoj } \\
\text { strukturi }\end{array}$ & $\mathbf{F 1}$ & F2 & F3 & F4 \\
\hline Uključenost u obitelj 1 & Uključenost u obitelj 1 & 0,66 & 0,10 & 0,22 & 0,08 \\
\hline Uključenost u obitelj 2 & Intrapersonalne snage 1 & 0,27 & $-0,03$ & 0,32 & 0,09 \\
\hline Afektivne snage 1 & Intrapersonalne snage 2 & 0,09 & $-0,04$ & 0,38 & 0,11 \\
\hline Uključenost u obitelj 3 & Intrapersonalne snage 3 & 0,20 & 0,13 & 0,37 & 0,08 \\
\hline Afektivne snage 2 & Intrapersonalne snage 4 & 0,05 & 0,05 & 0,43 & 0,3 \\
\hline Uključenost u obitelj 4 & Uključenost u obitelj 2 & 0,80 & 0,13 & 0,28 & 0,2 \\
\hline Afektivne snage 3 & Intrapersonalne snage 5 & 0,15 & 0,17 & 0,65 & 0,08 \\
\hline Uključenost u obitelj 5 & Intrapersonalne snage 6 & 0,17 & 0,12 & 0,36 & 0,09 \\
\hline Školsko funkcioniranje 1 & Školsko funkcioniranje 1 & 0,13 & 0,37 & 0,18 & 0,25 \\
\hline Uključenost u obitelj 6 & Uključenost u obitelj 3 & 0,79 & 0,16 & 0,24 & 0,12 \\
\hline Interpersonalne snage 4 & Školsko funkcioniranje 2 & 0,06 & 0,35 & 0,08 & 0,24 \\
\hline Intrapersonalne snage 3 & Interpersonalne snage 1 & 0,13 & 0,04 & 0,10 & 0,41 \\
\hline Intrapersonalne snage 4 & Intrapersonalne snage 7 & 0,01 & 0,02 & 0,66 & 0,14 \\
\hline Afektivne snage 4 & Intrapersonalne snage 8 & 0,04 & 0,13 & 0,77 & 0,02 \\
\hline Školsko funkcioniranje 2 & Školsko funkcioniranje 3 & 0,05 & 0,70 & 0,22 & 0,10 \\
\hline Afektivne snage 6 & Intrapersonalne snage 9 & 0,21 & 0,02 & 0,67 & 0,18 \\
\hline Intrapersonalne snage 7 & Intrapersonalne snage 10 & 0,22 & 0,13 & 0,32 & 0,26 \\
\hline Interpersonalne snage 7 & Interpersonalne snage 2 & 0,05 & 0,13 & 0,12 & 0,55 \\
\hline Školsko funkcioniranje 3 & Školsko funkcioniranje 4 & $-0,02$ & 0,72 & 0,14 & 0,15 \\
\hline Interpersonalne snage 8 & Interpersonalne snage 3 & 0,10 & 0,19 & 0,17 & 0,45 \\
\hline Interpersonalne snage 9 & Interpersonalne snage 4 & 0,03 & 0,05 & 0,22 & 0,63 \\
\hline Interpersonalne snage 10 & Interpersonalne snage 5 & 0,16 & 0,17 & 0,06 & 0,57 \\
\hline Školsko funkcioniranje 4 & Školsko funkcioniranje 5 & 0,05 & 0,70 & 0,10 & 0,16 \\
\hline Školsko funkcioniranje 5 & Školsko funkcioniranje 6 & 0,20 & 0,43 & $-0,00$ & $-0,03$ \\
\hline Intrapersonalne snage 10 & Intrapersonalne snage 11 & 0,17 & 0,15 & 0,40 & 0,21 \\
\hline Interpersonalne snage 11 & Interpersonalne snage 6 & 0,01 & 0,21 & 0,21 & 0,44 \\
\hline Interpersonalne snage 13 & Interpersonalne snage 7 & $-0,07$ & 0,21 & 0,14 & 0,62 \\
\hline Školsko funkcioniranje 7 & Školsko funkcioniranje 7 & 0,01 & 0,67 & 0,11 & 0,13 \\
\hline Intrapersonalne snage 11 & Intrapersonalne snage 12 & $-0,00$ & 0,19 & 0,34 & 0,20 \\
\hline Školsko funkcioniranje 8 & Školsko funkcioniranje 8 & 0,09 & 0,46 & $-0,01$ & 0,26 \\
\hline Školsko funkcioniranje 9 & Školsko funkcioniranje 9 & 0,05 & 0,69 & 0,01 & 0,14 \\
\hline \% objašnjene varijance & & $7 \%$ & $11 \%$ & $11 \%$ & $8 \%$ \\
\hline
\end{tabular}




\section{Konfirmatorna faktorska analiza na drugoj polovici podataka}

Kako bi se provjerilo odgovara li više izvorna peterofaktorska struktura podacima ili faktorska struktura na koju je uputila eksploratona analiza iz prve faze analize, učinjene su dvije konfirmatorne faktorske analize na drugoj polovici podataka $\left(\mathrm{N}_{2}=423\right)$, čiji su rezultati prikazani u Tablici 4 . S obzirom na parametre prikladnosti, moguće je zaključiti kako izvorni peterofaktorski model ne odgovara dovoljno dobro podacima našeg istraživanja da bi se mogao smatrati prikladnim jer jedino relativni hi-kvadrat test odgovara uvjetima prikladnosti modela. Nadalje, iako podaci bolje pristaju četverofaktorskom modelu sa smanjenim brojem čestica, pristajanje modela podacima nije potpuno. Budući da omjer hi-kvadrat testa i stupnjeva slobode te RMSEA u potpunosti sugeriraju prikladnost modela, a da su vrijednosti ostalih parametara (GFI, CFI) značajno bliže granici od 0,90, može se zaključiti kako podaci ipak bolje odgovaraju četverofaktorskom modelu. Provjerom pouzdanosti pokazalo se da sve četiri podskale imaju zadovoljavajuću pouzdanost te su formirana četiri ukupna rezultata kao sume procjena po česticama koje čine pojedinu podskalu. Deskriptivni parametri tih podskala prikazani su u Tablici 5.

Tablica 4. Rezultati konfirmatornih faktorskih analiza za dva modela

\begin{tabular}{lcc}
\hline & $\begin{array}{c}\text { izvorna 5-faktorska } \\
\text { struktura (52 čestice) }\end{array}$ & $\begin{array}{c}\text { 4-faktorska struktura } \\
\text { (31 čestica) }\end{array}$ \\
\hline hi-kvadrat & 3330,16 & 1034,68 \\
df & 1264 & 428 \\
hi-kvadrat/df & 2,63 & 2,42 \\
RMSEA & 0,07 & 0,05 \\
GFI & 0,76 & 0,86 \\
CFI & 0,70 & 0,85 \\
\hline
\end{tabular}

Tablica 5. Psihometrijska obilježje podskala formiranih iz Upitnika BERS-2

\begin{tabular}{lcccccc}
\hline & M & SD & raspon & Cronbach $\alpha$ & asimetričnost & spljoštenost \\
\hline $\begin{array}{l}\text { Uključenost u } \\
\text { obitelj }\end{array}$ & 7,79 & 1,65 & $1-9$ & 0,82 & $-1,48$ & 1,99 \\
$\begin{array}{l}\text { Školsko } \\
\text { funkcioniranje }\end{array}$ & 17,57 & 5,09 & $2-27$ & 0,82 & $-0,39$ & 0,18 \\
$\begin{array}{l}\text { Intrapersonalne } \\
\text { snage }\end{array}$ & 27,87 & 5,03 & $11-36$ & 0,81 & $-0,69$ & 0,39 \\
$\begin{array}{l}\text { Interpersonalne } \\
\text { snage }\end{array}$ & 17,41 & 2,90 & $7-21$ & 0,73 & $-0,84$ & 0,55 \\
\hline
\end{tabular}




\section{Konvergentna valjanost hrvatske inačice BERS-2 upitnika}

Kako bi se istražila konvergentna valjanost hrvatske inačice BERS-2 upitnika, provedene su korelacijske analize između rezultata na podskalama BERS-2 te mjera emocionalne kompetentnosti, zadovoljstva obitelji te školskog postignuća. Rezultati tih analiza prikazani su u Tablici 6. Školski uspjeh je očekivano značajno povezan s rezultatom na podskali školskog funkcioniranja. Podskale emocionalne kompetentnosti su značajno povezane i s intrapersonalnim, ali i interpersonalnim snagama, pri čemu je najviša povezanost utvrđena između sposobnosti imenovanja i izražavanja emocija i intrapersonalnih snaga. Zadovoljstvo obitelji visoko je značajno povezano s uključenošću u obitelj, što upućuje na konvergentnu valjanost podskale uključenosti u obitelj BERS-2 upitnika.

Tablica 6. Povezanost rezultata na podskalama BERS-2 upitnika i mjera sličnih konstrukata

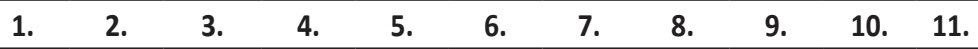

1. spol

2. dob

$0,11^{*}$

3. školski uspjeh

$0,24 * *-0,11^{*}$

4. zadovoljstvo obitelji

$\begin{array}{lll}-0,08 & -0,08 & -0,06\end{array}$

5. imenovanje i izražavanje emocija

$\begin{array}{lll}-0,03 & 0,03 & -0,12 * * \\ 0,36 * *\end{array}$

6. uočavanje $\mathrm{i}$ razumijevanje emocija

$0,20 * \quad-0,00 \quad 0,05 \quad 0,19 * * 0,52 * *$

7. upravljanje emocijama

$-0,04 \quad 0,07 \quad 0,04 \quad 0,32 * * 0,44 * * 0,47^{* *}$

8. uključenost u obitelj

$0,01 \quad-0,07 \quad 0,02 \quad 0,67^{* *} 0,30 * * 0,16^{* *} 0,22 * *$

9. školsko funkcioniranje

$0,08 \quad-0,06 \quad 0,37^{* *} \quad 0,14^{* *} \quad 0,06 \quad 0,06 \quad 0,23 * * 0,21^{* *}$

10. intrapersonalne snage

$0,09-0,03 \quad-0,03 \quad 0,33 * * 0,44 * * 0,35^{* *} 0,26 * * 0,43 * * 0,30 * *$

11. interpersonalne snage

${ }^{*} p<0,05 ; * p<0,01$ 


\section{Spolne i dobne razlike u rezultatima na podskalama upitnika BERS-2}

U posljednjem dijelu analize, provedene su četiri dvosmjerne analize varijance kako bi se ispitalo razlikuju li se adolescenti u rezultatima na podskalama revidiranog BERS-2 upitnika s obzirom na dob i spol. Rezultati tih analiza prikazani su u Tablici 7. Moguće je zaključiti kako djevojke ostvaruju značajno više rezultate na mjerama školskog funkcioniranja i interpersonalnih snaga, dok je razlika u uključenosti u obitelj tek na granici značajnosti $(p=0,05)$. Intrapersonalne snage jednakima su procijenili djevojke i mladići. Dob se nije pokazala relevantnom za niti jednu varijablu osim školskog funkcioniranja, u kojem su se značajno uspješnijima procijenili najmlađi sudionici u odnosu na sve ostale među kojima pak nije bilo razlika.

Tablica 7. Usporedba rezultata na podskalama revidiranog BERS-2 upitnika s obzirom na spol i dob sudionika

\begin{tabular}{|c|c|c|c|c|c|c|}
\hline Podskale BERS-2 & \multicolumn{2}{|c|}{ nezavisne varijable } & $\mathbf{N}$ & $\mathbf{M}$ & SD & $F(d f)$ \\
\hline \multirow{14}{*}{$\begin{array}{l}\text { Uključenost u } \\
\text { obitelj }\end{array}$} & \multirow[t]{2}{*}{ spol } & $M$ & 366 & 2,62 & 0,51 & \multirow{2}{*}{$\begin{array}{c}3,75 \\
(1,823)\end{array}$} \\
\hline & & ž & 471 & 2,55 & 0,57 & \\
\hline & \multirow[t]{4}{*}{ dob } & 15 godina & 191 & 2,63 & 0,50 & \multirow{4}{*}{$\begin{array}{c}1,26 \\
(3,823)\end{array}$} \\
\hline & & 16 godina & 221 & 2,57 & 0,57 & \\
\hline & & 17 godina & 194 & 2,61 & 0,52 & \\
\hline & & 18 godina & 234 & 2,55 & 0,57 & \\
\hline & \multirow[t]{8}{*}{ spolxdob } & M, 15 godina & 93 & 2,67 & 0,43 & \multirow{8}{*}{$\begin{array}{c}0,46 \\
(3,823)\end{array}$} \\
\hline & & M, 16 godina & 110 & 2,62 & 0,55 & \\
\hline & & M, 17 godina & 75 & 2,69 & 0,47 & \\
\hline & & M, 18 godina & 93 & 2,55 & 0,57 & \\
\hline & & Ž, 15 godina & 100 & 2,59 & 0,56 & \\
\hline & & Ž, 16 godina & 113 & 2,52 & 0,59 & \\
\hline & & Ž, 17 godina & 122 & 2,57 & 0,55 & \\
\hline & & Ž, 18 godina & 143 & 2,55 & 0,57 & \\
\hline
\end{tabular}




\begin{tabular}{|c|c|c|c|c|c|c|}
\hline Podskale BERS-2 & \multicolumn{2}{|c|}{ nezavisne varijable } & $\mathbf{N}$ & M & SD & $F(d f)$ \\
\hline \multirow{14}{*}{$\begin{array}{l}\text { Školsko } \\
\text { funkcioniranje }\end{array}$} & \multirow[t]{2}{*}{ spol } & $M$ & 366 & 1,91 & 0,57 & \multirow{2}{*}{$\begin{array}{c}6,10^{*} \\
(1,823)\end{array}$} \\
\hline & & ž & 471 & 2,01 & 0,55 & \\
\hline & \multirow[t]{4}{*}{ dob } & 15 godina & 191 & 2,06 & 0,51 & \multirow{4}{*}{$\begin{array}{c}2,94 * \\
(1,823)\end{array}$} \\
\hline & & 16 godina & 221 & 1,94 & 0,59 & \\
\hline & & 17 godina & 194 & 1,94 & 0,59 & \\
\hline & & 18 godina & 234 & 1,95 & 0,54 & \\
\hline & \multirow[t]{8}{*}{ spolxdob } & M, 15 godina & 93 & 2,03 & 0,55 & \multirow{8}{*}{$\begin{array}{c}0,69 \\
(3,823)\end{array}$} \\
\hline & & M, 16 godina & 110 & 1,92 & 0,55 & \\
\hline & & M, 17 godina & 75 & 1,87 & 0,69 & \\
\hline & & M, 18 godina & 93 & 1,85 & 0,50 & \\
\hline & & Ž, 15 godina & 100 & 2,08 & 0,50 & \\
\hline & & Ž, 16 godina & 113 & 1,96 & 0,62 & \\
\hline & & Ž, 17 godina & 122 & 1,99 & 0,52 & \\
\hline & & Ž, 18 godina & 143 & 2,02 & 0,55 & \\
\hline \multirow{14}{*}{$\begin{array}{l}\text { Intrapersonalne } \\
\text { snage }\end{array}$} & \multirow[t]{2}{*}{ spol } & M & 366 & 2,31 & 0,43 & \multirow{2}{*}{$\begin{array}{c}0,71 \\
(1,823)\end{array}$} \\
\hline & & Ž & 471 & 2,34 & 0,40 & \\
\hline & \multirow[t]{4}{*}{ dob } & 15 godina & 191 & 2,34 & 0,39 & \multirow{4}{*}{$\begin{array}{c}0,08 \\
(3,823)\end{array}$} \\
\hline & & 16 godina & 221 & 2,32 & 0,46 & \\
\hline & & 17 godina & 194 & 2,34 & 0,42 & \\
\hline & & 18 godina & 234 & 2,34 & 0,41 & \\
\hline & \multirow[t]{8}{*}{ spolxdob } & M, 15 godina & 93 & 2,34 & 0,35 & \multirow{8}{*}{$\begin{array}{c}2,26 \\
(3,823)\end{array}$} \\
\hline & & M, 16 godina & 110 & 2,33 & 0,44 & \\
\hline & & M, 17 godina & 75 & 2,36 & 0,48 & \\
\hline & & M, 18 godina & 93 & 2,25 & 0,44 & \\
\hline & & Ž, 15 godina & 100 & 2,34 & 0,41 & \\
\hline & & Ž, 16 godina & 113 & 2,31 & 0,45 & \\
\hline & & Ž, 17 godina & 122 & 2,33 & 0,38 & \\
\hline & & Ž, 18 godina & 143 & 2,40 & 0,37 & \\
\hline
\end{tabular}




\begin{tabular}{|c|c|c|c|c|c|c|}
\hline Podskale BERS-2 & & varijable & $\mathbf{N}$ & M & SD & $F(d f)$ \\
\hline \multirow{14}{*}{$\begin{array}{l}\text { Interpersonalne } \\
\text { snage }\end{array}$} & \multirow[t]{2}{*}{ spol } & $M$ & 366 & 2,42 & 0,45 & \multirow{2}{*}{$\begin{array}{r}32,56 * * \\
(1,823)\end{array}$} \\
\hline & & $\check{Z}$ & 471 & 2,58 & 0,35 & \\
\hline & \multirow[t]{4}{*}{ dob } & 15 godina & 191 & 2,52 & 0,41 & \multirow{4}{*}{$\begin{array}{c}0,85 \\
(3,823)\end{array}$} \\
\hline & & 16 godina & 221 & 2,53 & 0,40 & \\
\hline & & 17 godina & 194 & 2,49 & 0,42 & \\
\hline & & 18 godina & 234 & 2,51 & 0,40 & \\
\hline & \multirow[t]{8}{*}{ spolxdob } & M, 15 godina & 93 & 2,48 & 0,45 & \multirow{8}{*}{$\begin{array}{c}0,74 \\
(3,823)\end{array}$} \\
\hline & & M, 16 godina & 110 & 2,44 & 0,43 & \\
\hline & & M, 17 godina & 75 & 2,41 & 0,50 & \\
\hline & & M, 18 godina & 93 & 2,39 & 0,44 & \\
\hline & & Ž, 15 godina & 100 & 2,57 & 0,35 & \\
\hline & & Ž, 16 godina & 113 & 2,62 & 0,35 & \\
\hline & & Ž, 17 godina & 122 & 2,55 & 0,35 & \\
\hline & & Ž, 18 godina & 143 & 2,60 & 0,35 & \\
\hline
\end{tabular}

${ }^{*} p<0,05 ; * *<0,01$

\section{RASPRAVA}

Cilj ovoga istraživanja bio je provjeriti strukturu i ostale psihometrijske značajke hrvatskog prijevoda upitnika BERS-2 budući da je riječ o upitniku koji se široko primjenjuje u praksi u zemljama engleskog govornog područja, a postoji i službena inačica instrumenta na španjolskom jeziku. Također, riječ je o instrumentu koji ima potencijal biti korisno trijažno sredstvo u praksi, u smislu identificiranja jakih snaga djece i mladih kako bi se mogli planirati preventivni i intervencijski planovi u području socio-emocionalnog učenja ili jačanja kompetencija nužnih za ostvarivanje optimalnih razvojnih ishoda djece i mladih. Eksploratorna faktorska analiza hrvatskog prijevoda uputila je na značajno različitu strukturu instrumenta u odnosu na izvornik te primjene u kojima je potpuno ili uglavnom potvrđena njegova izvorna struktura (Epstein, 2004.; Sointu i sur., 2014.; Epstein i Ramos, 2004). Na hrvatskom uzorku jedino je u istraživanju Merkaš (2012.) korišten ovaj upitnik, pri čemu je autorica potvrdila izvornu strukturu upitnika. Razliku u strukturi u odnosu na ovo istraživanje moguće je tražiti u dobnoj strukturi uzoraka budući da su u istraživanju Merkaš (2012.) sudjelovali rani adolescenti (od petog do sedmog razreda OŠ), dok su u ovom istraživanju sudjelovali srednjoškolci prosječne dobi 17 godina. Podaci ovog istraživanja sličniji su onima koje su u svom istraživanju dobili Furlong i suradnici (2007.), a koji upućuju na potrebu 
skraćivanja upitnika te bolje pristajanje četverofaktorske strukture. Naše je istraživanje, u odnosu na izvornik, pokazalo najveću sličnost u faktoru školskog funkcioniranja gdje postoji razlika u dvije čestice, od kojih je jedna iz izvorne strukture izostavljena zbog nedovoljnog zasićenja, a jedna dodana iako je u izvornoj strukturi pripadala podskali interpersonalnih snaga. Naime, u izvorniku se radi o čestici «Razmišljam o tome što bi se moglo dogoditi prije nego što odlučim napraviti nešto». Moguće je da su sudionici u našem istraživanju ovu česticu procjenjivali imajući na umu školski kontekst kao referentnu točku, s obzirom da je istraživanje bilo provedeno u samoj školi.

Razlike u podskali uključenosti u obitelj su značajne na način da prema našim podacima tu podskalu čine samo tri čestice, dok ih je u izvorniku čak 10. Dio tih čestica nije imao značajno zasićenje na niti jednom faktoru (primjerice, «ldem na religijske aktivnosti», "Dobro se slažem s braćom i sestrama»), odnosno na nekoliko faktora zasićenje oko 0,30 do 0,40 (primjerice, "Poštujem pravila u svojoj kući»). Nadalje, neke su čestice imale značajno zasićenje na drugom faktoru, primjerice, čestica «Imam jako puno povjerenja u najmanje jednu osobu» te je dodana podskali intrapersonalnih snaga, gdje zapravo po svom sadržaju i pripada. Naime, iako je u izvorniku ova čestica dio obiteljske podskale, moguće ju je smatrati i intrapersonalnom snagom jer se ne navodi da je riječ o članu obitelji - naglasak je na osobnom povjerenju u nekoga. Stoga nam se i sadržajno čini da ova čestica bolje odgovara intrapersonalnom faktoru jer se tu ne misli nužno na obitelj pa nije jasno zašto je u izvornoj verziji ta čestica na obiteljskoj podskali. Slično je i s česticom «Uključujem se u aktivnosti zajednice» koja zapravo ne implicira obiteljski kontekst pa je razumljivo da ne čini sastavni dio te podskale kao što je to slučaj u izvorniku. I u ovom slučaju ta se čestica pokazala najprimjerenijom kao sastavni dio podskale intrapersonalnih snaga. lako su u konačnici samo tri čestice ostale na podskali Uključenosti u obitelj, pokazale su visoku pouzdanost, a ukupan je rezultat visoko pozitivno povezan s rezultatima Skale zadovoljstva obitelji iz upitnika FACES IV (Olson, Gorall i Tiesel, 2006.) što govori u prilog njezinoj valjanosti pa procjenjujemo korisnim zadržati je dijelom revidirane inačice BERS-2 upitnika.

Razlike su očite i u izvornim podskalama intrapersonalnih i afektivnih snaga koje u izvornoj verziji čine dvije odvojene podskale, a u našem su se istraživanju čestice s tih podskala izdvojile na zajedničkom faktoru. Razlog je dijelom i u samom sadržaju tvrdnji i donekle nejasnoj konceptualizaciji afektivnih i intrapersonalnih snaga. Naime, prema Epsteinu i sur. (2004), podskala intrapersonalnih snaga uključuje djetetovo poimanje vlastitih kompetencija i postignuća, dok se afektivne snage odnose na pružanje i prihvaćanje emocija od drugih. Ipak, i u izvornoj verziji upitnika postoje odstupanja od takve konceptualizacije budući da je, primjerice, čestica «Pitam za pomoć kada mi je to potrebno» u izvorniku dio podskale afektivnih snaga što zapra- 
vo ne odgovara opisu same podskale. U našem istraživanju ta je čestica sastavni dio faktora intrapersonalnih snaga, što i sadržajno odgovara konceptu intrapersonalnih snaga kako su ga predložili autori upitnika. Nadalje, čestica «Stalo mi je do toga kako se drugi ljudi osjećaju» u izvorniku je činila podskalu afektivnih snaga, međutim, u ovom se istraživanju povezala s česticama koje se odnose na intrapersonalne snage koje uključuju i emocionalne kompetencije. Slično je i s tvrdnjom «Osjećam se blisko i povezano s drugima» koja u izvorniku također pripada afektivnim snagama, ali u našem istraživanju čini faktor intrapersonalnih snaga. Navedene razlike vjerojatno su posljedica nedovoljno jasnog razlikovanja između afektivne i intrapersonalne dimenzije budući da obje dijelom uključuju i emocionalne kompetencije. Stoga se čini primjerenijim objediniti čestice koje se izvorno odnose na afektivne i intrapersonalne snage ili konceptualno jasnije razgraničiti ta dva područja. Svakako, rezultati provjere strukture upitnika na našem uzorku upućuju na potrebu uvažavanja ovih pokazatelja konstruktne valjanosti pri daljnjem korištenju na našim uzorcima adolescenata.

Jedan od istraživačkih problema odnosio se i na ispitivanje rodnih i dobnih razlika u kompetencijama izmjerenima BERS-2 upitnikom. Provedene analize pokazale su kako djevojke, u odnosu na mladiće, uspješnijim procjenjuju školsko funkcioniranje i interpersonalne snage. Kada je riječ o školskom funkcioniranju, ovi rezultati ne iznenađuju jer je prednost djevojaka u školskom kontekstu dobro dokumentirana brojnim istraživanjima, bilo da je riječ o školskom postignuću (Pomerantz, Altermatt i Saxon, 2002.; Baharudin i Sheereen Zulkefly, 2009.; Jokić i Ristić Dedić, 2010.; Koludrović i Radnić, 2013.), predanosti školskim obvezama (Roviš i Bezinović, 2011.) ili motivaciji u školskom kontekstu (Koludrović i Reić Ercegovac, 2013.).

S obzirom na interpersonalne snage, prednost djevojaka moguće je tumačiti u kontekstu bolje razvijenih socijalnih vještina, o čemu govore brojna istraživanja (Leppänen i Hietanen, 2001.; MacDermott i sur., 2009.; Pečjak i sur., 2009). I na djeci predškolskog uzrasta, rezultati istraživanja pokazuju kako i roditelji i odgojitelji djevojčice procjenjuju uspješnijima u socijalnim vještinama u odnosu na dječake (Abdi, 2010.; Tatalović Vorkapić i Lončarić, 2014.; Ljubetić, Reić Ercegovac i Draganja, 2019.), a ti rezultati ostaju relativno konzistentni i u odrasloj dobi. U podlozi ovih razlika mogu biti rane razlike u temperamentu koje upućuju na više razvijenu samokontrolu djevojčica u odnosu na dječake (Else-Quest i sur., 2006.), kao i različita socijalizacija dječaka i djevojčica koja ide u smjeru snažnijeg poticanja djevojčica na socijalno prihvatljivo ponašanje s naglaskom na prosocijalno ponašanje, empatiju i brigu za druge. Žene općenito ostvaruju više rezultate na ugodnosti (Costa, Terracciano i McCrae, 2001.) kao dimenziji ličnosti, što je povezano upravo sa socijalnom domenom, odnosno srdačnim i toplim odnosima s drugima, brižnošću za druge i sl. U intrapersonalnim snagama nije utvrđena značajna spolna razlika. S obzirom na složenost ovog 
konstrukta te činjenicu kako istraživanja diljem svijeta nisu konzistentna kada su u pitanju spolne razlike u ovom području, dobiveni rezultat ne iznenađuje. Dok neka istraživanja upućuju na veću emocionalnu samoefikasnost adolescenata u odnosu na djevojke (Reić Ercegovac, Maglica i Ljubetić, 2019.) i bolju emocionalnu regulaciju adolescenata u odnosu na adolescentice (Gaspar i sur., 2018.), postoje istraživanja koja su utvrdila kako nema spolnih razlika kad su u pitanju intrapersonalne (pa čak interpersonalne) kompetencije (Avsec i sur., 2020.) ili pak razumijevanje i regulacija emocija (Garaigordobil, 2020.).

S obzirom na složenost konstrukta socio-emocionalnih kompetencija i potrebu pronalaženja instrumenta ili načina mjerenja koji će osigurati valjane podatke, neke od preporuka za buduća istraživanja (i praksu) zasigurno se odnose na procjenjivanje socio-emocionalnih kompetencija koristeći mix-method dizajne i različite oblike procjenjivanja kao što su, primjerice intervjui, opservacije, dnevnici i dr. (vidi više u Cefai i Cavioni, 2014.). Većina trenutnih alata za procjenu temelji se na upitnicima, check-listama ili procjenama učitelja/roditelja (Elias i sur., 2016.; Cefai i sur., 2018.; Cefai i Cavioni, 2014.; prema Cefai i sur., 2018.). Müller i suradnici (2020.) proveli su sustavni pregled preko 149 instrumenta za procjenu ovih kompetencija (uključujući i BERS-2) te zaključili kako ih se čak $88,6 \%$ odnosi na različite upitnike. Stoga preporučuju promišljanje o alternativnim metodama koje bi kombinirale kvantitativne i kvalitativne pristupe nakon kojih bi se mogli dobiti sveobuhvatniji rezultati o socio-emocionalnim kompetencijama učenika.

\section{ZAKLJUČAK}

Rezultati našeg istraživanja nisu poduprli izvornu strukturu upitnika BERS-2 na uzorku hrvatskih adolescenata, no dijelom su u skladu su s rezultatima Furlonga i sur. (2007.). Naime, čestice upitnika mogu se podijeliti na područja koja odgovaraju interpersonalnim i intrapersonalnim snagama djeteta koja se manifestiraju i u odnosu prema samome sebi i u socijalnim interakcijama te na područja specifičnog funkcioniranja djeteta u dva ključna socijalna konteksta, a to su obitelj i škola. Takva četverofaktorska konceptualizacija čini se primjerenijom. lako provedene analize ne podupiru u potpunosti predloženi četverofaktorski model, čini se svakako primjerenijim našim podacima u odnosu na izvornu konceptualizaciju, a što upućuje na potrebu daljnje provjere ovakvog koncepta.

U praksi, revidirana inačica BERS-2 upitnika na hrvatskom jeziku bi, u formi koja se pokazala relativno valjanom u našem istraživanju, mogla poslužiti identifikaciji jakih snaga adolescenata, što može biti dobro polazište za preventivne i tretmanske intervencije koje imaju za cilj jačanja njihovih kapaciteta, povećanje akademskih postignuća i opće dobrobiti djece i mladih. 


\section{LITERATURA}

1. Abdi, B. (2010). Gender differences in social skills, problem behaviours and academic competence of Iranian kindergarten children based on their parent and teacher ratings. Procedia Social and Behavioural Sciences, 5, 1175-1179. https://doi.org/10.1016/j.sbspro.2010.07.256.

2. Ajduković, M. \& Kolesarić, V. (2003). Etički kodeks istraživanja s djecom. Vijeće za djecu Vlade Republike Hrvatske. Zagreb: Državni zavod za zaštitu obitelji, materinstva i mladeži.

3. Avsec, A., Belasheva, I., Cenek, J., Mohorić, T., Takšić, V. \& Zager Kocjan, G. (2020). Cross-cultural and gender measurement invariance of the Intrapersonal and interpersonal emotional competence questionnaire. Psihologijske teme, 29 (1), 167-190. https://doi.org/10.31820/pt.29.1.10.

4. Baharudin, R. \& Sheereen Zulkefly, N. (2009). Relationships with father and mother, self-esteem and academic achievement amongst college students. American Journal of Scientific Research, 6, 86-94.

5. Bar-On, R. (2005). The Bar-On model of emotional-social intelligence. Psicothema, 18, Suplemen.1, 13-25.

6. Bernier, A., Carlson, S.M., Deschênes, M. \& Matte-Gagné, C. (2012). Social factors in the development of early executive functioning: A closer look at the caregiving environment. British Journal of Social Psychology 15 (1), 12-24. https:// doi.org/10.1111/j.1467-7687.2011.01093.x.

7. Blythe, D., Weissberg, R. P. \& Durlak, J. (2019). Applied social and emotional learning (SEL) research thet fosters quality practise at scale. Journal of Research in Innovative Teaching \& Learning, 12 (1), 4-6. https://doi.org/10.1108/JRIT-022019-0041.

8. Böddi, Z. \& Serfőző, M. (2019). Brief introduction of preschools and preschool teacher training in Hungary. Koragyermekkori kutatások metodológiája. Gyermeknevelés 2019 (2-3), 187-194. https://doi.org/10.31074/201923187194

9. Cabrera-Nguyen, P. (2010). Author guidelines for reporting scale development and validation results in the Journal of the Society for Social Work and Research. Journal of the Society for Social Work and Research, 1, 99-103. https://doi. org/10.5243/jsswr.2010.8.

10. CASEL Briefs (2007). Background ond social and emotional learning (SEL). Collaborative for Academic, Social and Emotional Learning. Illinois: University of Illinois.

11. CASEL Guide (2015). Effective social and emotional learning programs. Collaborative for academic, social, and emotional learning. Illinois: University of Illinois.

12. Cefai, C., Bartolo, P. A., Cavioni, V. \& Downes, P. (2018). strenghtening social and emotional education as a core curricular area across the EU. A review of 
the international evidence, NEESET II report. Luxembourg: Publications Office of the European Union. https://doi.org/10.2766/664439.

13. Cefai, C. \& Cavioni, V. (2014). Social and emotional education in primary school: integrating theory and research into practise. New York: Springer. Chicago, IL: Collaborative for Academic, Social, and Emotional Learning.

14. Cohen, J. \& Sandy, S. (2003). Perspectives in social-emotional education: Theoretical foundations and new evidence-based developments in current practice. Perspectives in Education, 21 (4), 41-54.

15. Cohen, J. (2001). Social and emotional education: Core principles and practices. In Cohen, J. (ed.), Caring classrooms/intelligent schools: The social emotional education of young children. New York: Teachers College Press.

16. Collaborative for Academic, Social, and Emotional Learning (CASEL). (2017). Preuzeto s: https://casel.org/core-competencies/ (02.04.2020.)

17. Costa, P. T., Terracciano, A. \& McCrae, R. R. (2001). Gender differences in personality traits across cultures: Robust and surprising findings. Journal of Personality and Social Psychology, 81, 322-331. https://doi.org/10.1037/0022-3514.81.2.322.

18. Curran, P. J., West, S. G. \& Finch, J. F. (1996). The robustness of test statistics to non-normality and specification error in confirmatory factor analysis. Psychological Methods, 1 (1), 16-29. https://doi.org/10.1037/1082-989X.1.1.16.

19. Denham, S. A. \& Brown, C. (2010). Plays nice with others: Social-emotional learning and academic success. Early Education and Development, 21 (5), 652680. https://doi.org/10.1080/10409289.2010.497450.

20. Duppong Hurley, K., Lambert, M. C., Epstein, M. H. \& Stevens, A. (2015). convergent validity of the Strength-based behavioral and emotional rating scale with youth in a residential setting. The Journal of Behavioral Health Services \& Research, 42 (3), 346-354. https://doi.org/10.1007/s11414-013-9389-0.

21. Durlak, J. A., Weissberg, R. P., Dymnicki, A. B., Taylor, R. D. \& Schellinger, K. B. (2011). The impact of enhancing students' social and emotional learning: A meta-analysis of school-based universal interventions. Child Development, 82 (1), 405-432.

22. Durlak, J. A., Domitovich, C. E., Weissberg, R. P., \& Gulotta, T. P. (2015). Handbook of social and emotional learning: Research and practice. New York: Guilford Press.

23. Else-Quest, N. M., Shibley Hyde, J., Goldsmith, H. \& van Hulle, C. A. (2006). Gender differences in temperament: A meta-analysis. Psychological Bulletin, 132 (1), 33-72. https://doi.org/10.1037/0033-2909.132.1.33.

24. Epstein, M. H. (2004). Behavioral and emotional rating scale - 2nd edition: $A$ strengths-based approach to assessment. Austin: PRO-ED. 
25. Epstein, M. H., Mooney, P., Ryser, G., Pierce, C. D. (2004). Validity and reliability of the Behavioral and emotional rating scale (2nd edition): Youth rating scale. Research on Social Work Pratices, 14 (5), 358-367. https://doi. org/10.1177/1049731504265832.

26. Epstein, M. H., Ramos, J. (2004). BERS-2 summary forms, Spanish version. Austin: PRO-ED.

27. Furlong, M. J., Sharkey, J. D., Boman, P. \& Caldewell, R. (2007). Cross-validation of the Behavioural ratting scale-2 youth version: An exploration of strenght-based latent traits. Journal of Child and Family Studies, 16, 696-711. https://doi. org/10.1007/s10826-006-9117-y.

28. Garaigordobil, M. (2020). Intrapersonal intelligence during adolescence: Sex differences, connection with other variables, and predictors. European Journal of Investigation in Health, Psychology and Education, 13 (3), 899-914. https:// doi.org/10.3390/ejihpe10030064.

29. Gaspar, T., Cerqueira, A., Branquinho, C. \& Gaspar de Matos, M. (2018). Dimensions of social and personal skills in children and adolescents: Age and gender differences. International Journal of Development Research, 8 (1), 18394-18400.

30. Gil-Olarte Márquez, P., Palomera Martín, R. \& Brackett, M. A. (2006). Relating emotional intelligence to social competence and academic achievement in high school students. Psicothema 18, supl.: 118-123. Preuzeto s: https://www.ncbi. nlm.nih.gov/pubmed/17295968 (1.3.2020.)

31. Gravetter, F. \& Wallnau, L. (2014). Essentials of statistics for the behavioral sciences (8th ed.). Belmont: Wadsworth.

32. Hu, L. \& Bentler, P. M. (1999). Cutoff criteria for fit indexes in covariance structure analysis: Conventional criteria versus new alternatives. Structural Equation Modeling: A Multidisciplinary Journal, 6, 1-55. https://doi. org/10.1080/10705519909540118.

33. Hui, C. H. \& Triandis, H. C. (1985). Measurement in cross-cultural psychology: A review and comparison of strategies. Journal of Cross-Cultural Psychology, 16, 131-152. https://doi.org/10.1177/0022002185016002001.

34. Humphrey, N., Kalambouka, A., Wigelsworth, M., Lendrum, A., Deighton, J. \& Wolpert, M. (2011). Measures of social and emotional skills for children and young people: A Systematic review. Educational and Psychological Measurement, 71 (4), 617-637. https://doi.org/10.1177/0013164410382896.

35. Jokić, B. \& Ristić Dedić, Z. (2010). Razlike u školskom uspjehu učenika trećih i sedmih razreda osnovnih škola u Republici Hrvatskoj s obzirom na spol učenika i obrazovanje roditelja: Populacijska perspektiva. Revija za socijalnu politiku, 17 (3), 345-362. https://doi.org/10.3935/rsp.v17i3.954. 
36. Koludrović, M., Radnić, I. (2013). Doprinos nekih osobnih i socijalnih čimbenika u objašnjenju školskog uspjeha u ranoj adolescenciji. Pedagogijska istraživanja, 10 (1), 65-77.

37. Koludrović, M. \& Reić Ercegovac, I. (2013). Motivacija i školski uspjeh: Dobne i spolne razlike u ciljnim orijentacijama. Napredak: Časopis za pedagogijsku teoriju i praksu, 154 (4), 493-509.

38. Leppänen, J. M. \& Hietanen, J. K. (2001). Emotion recognition and social adjustment in school-aged girls and boys. Scandinavian Journal of Psychology, 42 (5), 429-435. https://doi.org/10.1111/1467-9450.00255.

39. Ljubetić, M., Reić Ercegovac, I. \& Draganja, A. (2019). Razlike između odgojitelja i roditelja djece predškolske dobi u procjeni procjeni dječjih socio-emocionalnih kompetencija. Odgojno-obrazovne teme, 2 (3-4), 187-206.

40. MacDermott, S. T., Gullone, E., Allen, J. S., King, N. J. \& Tonge, B. (2010). The emotion regulation index for children and adolescents (ERICA): A psychometric investigation. Journal of Psychopathology and Behavioral Assessment, 32 (3), 301-314. https://doi.org/10.1007/s10862-009-9154-0.

41. Maggi, S., Irwin, L.J., Siddiqi, A. \& Hertzman, C., (2010). The social determinants of eary development: An overview. Journal of Paediatrics and Child Health, 46, 627-635. https://doi.org/10.1111/j.1440-1754.2010.01817.x.

42. Mahoney, J. L., Durlak, J. A. \& Weissberg, R. P. (2019). An update on social and emotional learning outcome research, Phi Delta Kappon, 100 (4), 18-23. https:// doi.org/10.1177/0031721718815668.

43. Merkaš, M. (2012). Uloga obitelji u razvoju socijalne kompetencije adolescenta. Doktorska disertacija. Zagreb: Filozofski fakultet, Sveučilište u Zagrebu.

44. Müller, F., Denk, A., Lubaway, E., Salzer, C., Kozina, A., Vršnik Perše, T., Rasmusson, M., Jugović, I., Lund Nielsen, B., Rozman, M., Ojsteršek, A. \& Jurko, S. (2020). Assesing social, emotional, and intercultural competences of students and school staff: Systematic literature review. Educational Research Review, 29. https://doi.org/10.1016/j.edurev.2019.100304.

45. Munjas Samarin, R. \& Takšić, V. (2009). Programi za poticanje emocionalne i socijalne kompetentnosti kod djece i adolescenta. Suvremena psihologija, 12 (2), 355-370.

46. Olson, D. H., Gorall, D. M. \& Tiesel, J. W. (2006). FACES IV package. Questionnaire \& answer sheet. Minneapolis: Life Innovations.

47. Payton, J., Weissberg, R. P., Durlak, J. A., Dymnicki, A. B., Taylor, R. D., Schellinger, K. B. \& Pachan, M. (2008). The positive impact of social and emotional learning for kindergarten to eight-grade students: Findings from three scientific reviews. Chicago: Collaborative for Academic, Social, and Emotional Learning (CASEL). 
48. Pečjak, S., Puklek Levpušček, M., Kalin, Valenčič Zuljan, M., Kalin, J. \& Peklaj, C. (2009). Students' social behaviour in relation to their academic achievement in primary and secondary school: Teacher's perspective. Psihologijske teme, 18 (1), 55-74.

49. Pomerantz, E. M., Altermatt, E. R. \& Saxon, J. L. (2002.). Making the grade but feeling distressed: Gender differences in academic performance and internal distress. Journal of Educational Psychology, 94, 396-404. https://doi. org/10.1037/0022-0663.94.2.396.

50. Reić Ercegovac, I., Koludrović, M. \& Mišurac, I. (2019). The contribution of the mathematics self-concept and subjective value of mathematics to mathematical achievement. Zbornik Instituta za pedagoška istraživanja, 51, 162-197. https:// doi.org/10.2298/ZIPI1901162R.

51. Reić Ercegovac, I., Maglica, T. \& Ljubetić, M. (2019). Odnos samopoimanja, subjektivne dobrobiti i školskog uspjeha tijekom adolescencije. U: Klasnić, I. (ur.), Zbornik radova međunarodne konferencije Suvremene teme u odgoju i obrazovanju-STOO. Zagreb: Učiteljski fakultet Sveučilišta u Zagrebu, 221-242.

52. Reid, R., Epstein, M., Pastor, D. \& Ryser, G. (2000). Strengths-based assessment differences across students with LD and EBD. Remedial and Special Education, 21, 346-355. https://doi.org/10.1177/074193250002100604.

53. Roviš, D. \& Bezinović, P. (2011). Vezanost za školu - analiza privrženosti školi i predanosti školskim obvezama kod srednjoškolaca. Sociologija i prostor: Časopis za istraživanja prostornog i sociokulturnog razvoja, 49, 2 (190), 185-208. https:// doi.org/10.5673/sip.49.2.4.

54. Schermelleh-Engel, K., Moosbrugger, H., \& Muller, H. (2003). evaluating the fit of structural equation models: Tests of significance and descriptive goodness-of-fit measures. Methods of Psychological Research Online, 8 (2), 23-74. Preuzeto s: http://citeseerx.ist.psu.edu/viewdoc/download?doi=10.1.1.509.4258\&rep=rep1\&type=pdf (15.12.2019).

55. Schonert-Reichl, K. A., Kitil, M. J. \& Hanson-Peterson, J. (2017). To reach the students, teach the teachers: A national scan of teacher preparation and social and emotional learning. A report prepared for the Collaborative for Academic, Social, and Emotional Learning (CASEL). Vancouver: University of British Columbia.

56. Sharkey, J., You, S., Morrison, G. \& Griffiths, A. (2009). Behavioural and emotional rating scale -2 parent report: Exploring a Spanish version with at-risk-students. Behavioural Disorders, 35(1), 53-65. Preuzeto s: www.jstor.org/stable/43153490 (2.12.2019.).

57. Sointu, E. T., Savolainen, H., Lambert, M. C., Lappalainen, K. \& Epstein, M. H. (2014). Behavioral and emotional strength-based assessment of Finnish elemen- 
tary students: psychometrics of the BERS-2. European Journal of Psychology of Education, 29, 1-19. https://doi.org/10.1007/s10212-013-0184-3.

58. Takšić, V. (2002). Upitnici emocionalne inteligencije (kompetentnosti) UEK. U: Lacković Grgin, K., Proroković, A., Ćubela, V. \& Penezić, Z. (ur.), Zbirka psihologijskih skala i upitnika (27-45). Zadar: Filozofski fakultet.

59. Tatalović Vorkapić, S. \& Lončarić, D. (2014). Validacija hrvatske verzije ljestvice socio-emocionalne dobrobiti i otpornosti predškolske djece. Hrvatska revija za rehabilitacijska istraživanja, 50 (2), 102-117.

60. The Aspen Institute National Commission on Social, Emotional, and Academic Development (2019). From a nation at risk to a nation at hope: Recommendations from the National Comission on Social, Emotional \& Academic Development, SAME, Washington, DC. Preuzeto s: http://nationathope.org/ report-from-the-nation/ (2.4.2020.).

61. Trochim, W. M. \& Donnelly, J. P. (2006). The research methods knowledge base (3rd ed.). Cincinnati: Atomic Dog.

62. Uhing, B., Mooney, P. \& Ryser, G. R. (2005). Differences in strenght assessment scores for youth with and without ED across the youth and parent rating scales of the BERS-2. Journal of Emotional and Behavioural Disorders, 13 (2), 181-187. https://doi.org/10.1177/10634266050130030601.

63. Van de Vijver, F. \& Hambleton, R. K. (1996). Translating tests: Some practical guidelines. European Psychologist, 1 (2), 89-99. https://doi.org/10.1027/10169040.1.2.8.

64. Zins, J. E., Bloodworth, M. R., Roger P. Weissberg, R. P. \& Walberg, H. J. (2004). The scientific base linking emotional learning to student success and academic outcomes. In: Zins, J. E., Weissberg, R. P., Wang, M. C., Walberg, H. J. (eds.), Building academic success on social and emotional learning: What does the research say?. New York and London: Teachers College, Columbia University 3-23. 
Ina Reić Ercegovac

Department of Psychology

Faculty of Humanities and Social Sciences

University of Split

Toni Maglica

Department of Pre-school Education

Faculty of Humanities and Social Sciences

University of Split

Maja Ljubetić

Department of Pedagogy

Faculty of Humanities and Social Sciences

University of Split

\section{BEHAVIOURAL AND SOCIO-EMOTIONAL COMPETENCIES OF HIGH SCHOOL STUDENTS: A VALIDATION OF THE CROATIAN VERSION OF BERS-2 QUESTIONNAIRE}

\section{ABSTRACT}

The aim of the paper was to examine the Croatian translation of the BERS-2 questionnaire on the sample of mid-adolescents, examine its convergent validity and analyse gender differences in behavioural and socio-emotional competencies of adolescents. 849 respondents participated in the research $156 \%$ female adolescents). General data questionnaire, Croatian version of the BERS-2 questionnaire, emotional competence questionnaire and family satisfaction scale were used. The conducted factor analyses have shown that the original five-factor BERS-2 structure does not correspond to the data, so a four-factor structure with a reduced number of items in comparison with the original was proposed as an optimum solution. Thus formed results have shown satisfactory psychometric characteristics for four groups of competencies. A significant correlation between the results shown on the BERS-2 questionnaire and school achievement, family satisfaction and emotional competencies indicates the convergent validity of the Croatian translation of the BERS-2. In comparison with boys, girls have achieved significantly higher results on the measures of school functioning and interpersonal strengths, while the measures of interpersonal strengths and involvement with family were assessed similarly by boys and girls. The results were analysed in the context of the data on the original 
BERS-2 questionnaire, the data on the verification of its features in other research and with regard to the existing knowledge about behavioural and socio-emotional competencies of adolescents. The limitations of the conducted research, as well as the need for further validation of the BERS-2 questionnaire are presented in the final part of the paper.

Key words: adolescents; BERS-2 questionnaire; socio-emotional competencies

\section{(c) (1) (9)}

Međunarodna licenca / International License:

Creative Commons Attribution-NonCommercial-NoDerivatives 4.0. 